\title{
Transformar o gioante num piomeu: as desventuras do projeto neoliberal na Venezuela (1989-1998)
}

Pedro Henrique de Moraes Cícero*

Resumo. O artigo faz um apanhado dos principais acontecimentos políticos que marcaram a sociedade venezuelana durante a década de 1990. Analisa-se, pois, os governos Carlos Andrés Pérez (1989-1993) e Rafael Caldera (1993-1998) os quais, cada um ao seu modo, empreenderam esforços para vincular o país ao modelo neoliberal de desenvolvimento. As circunstâncias que levaram ao completo fracasso dos programas de ajuste econômico implementados por ambos os governos - "A grande virada" e "Agenda Venezuela", respectivamente - influenciaram decisivamente na fulminante e vitoriosa ascensão do projeto político bolivariano durante as eleições nacionais ocorridas no final de 1998.

Palavras-chaves: Venezuela. Neoliberalismo. Década de 1990.

\section{Ascensão e Queda da “Venezuela Saudita” (1920-1989)}

A República Bolivariana da Venezuela é o quinto maior país da América do Sul e, atualmente, sua população ultrapassa os 28 milhões de habitantes, sendo que $89 \%$ dos quais habitam áreas urbanas, tais como as cidades de Caracas, Valencia e Maracaibo, todas elas metrópoles onde vivem mais de um milhão de pessoas.

\footnotetext{
* Universidade Estadual de Campinas. Instituto de Filosofia e Ciências Humanas. Programa de Mestrado em Ciência Política (mestrando). E-mail: puco02@yahoo. com.br
} 
Transformar o gigante num pigmeu...

Destes venezuelanos aproximadamente 13 milhões fazem parte da população economicamente ativa e o Produto Interno Bruto (PIB) para o ano de 2008 foi calculado em U\$ 335 bilhões (a trigésima maior economia do mundo), dos quais cerca de 115 bilhões são frutos diretos do comércio petroleiro ${ }^{1}$.

As cifras falam por si. Desde a década de 1920, quando superou o café como principal produto de exportação do país, a divisão dos proventos advindos da produção petroleira é fator crucial para se compreender as características da política econômica e social desenvolvida na Venezuela. Consta logo na introdução da clássica obra "Los Venezolanos y el Petróleo" a seguinte passagem:

Desde sus más remotos orígenes en el siglo XVI, en toda la historia de lo que ha venido ser la nación venezolana, no hay un hecho, un acontecimiento, un fenómeno, que haya ocasionada más radicales y profundas transformaciones, que haya alterado todos los aspectos de la vida nacional, que haya logrado cambiar la mentalidad, la conducta y los valores de toda la sociedad que pueda comparase con el impacto que el surgimiento de la riqueza petrolera tuvo para nuestro país [...] La apropiación directa o indirecta, por los actores económicos, de la renta petrolera percibida por el estado por un grupo muy exclusivo es la principal fuente de revoluciones y conflictos promovidos por los excluidos, que intentan sustituirlos o proclaman repartos más igualitarios y denuncian la corrupción (USLAR, 1990, p. 7).

Tal característica faz do país, segundo definição amplamente difundida na literatura, uma nação rentista ${ }^{2}$, cujo desenvolvimento está atrelado à incorporação dos lucros obtidos com o comércio do petróleo. O gráfico abaixo demonstra com propriedade o enorme peso do combustível para a economia nacional. A linha tracejada representa o que seria o PIB venezuelano se dele descontássemos todos os aportes gerados pela exportação do óleo. 
Gráfico 1 - PIB convencional x PIB petroleiro (1922-2002)

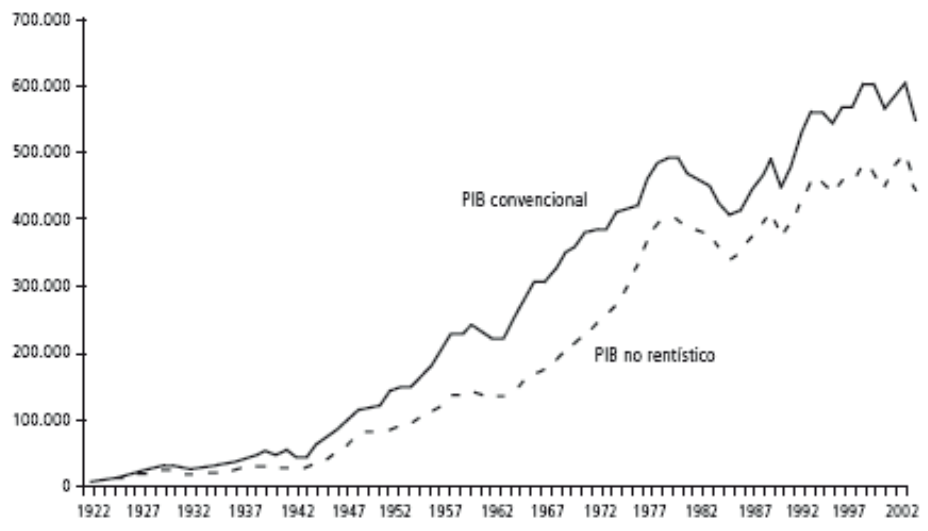

Fonte: Baptista (2005, p. 97)

Esta importante singularidade confere à economia do país um elevado grau de volatilidade, na medida em que os preços do combustível flutuam consideravelmente gerando, ciclicamente, períodos de bonança econômica, nos quais há relativa estabilidade política, seguidos por graves crises financeiras que, entre outros desdobramentos, produzem crises institucionais.

Nesse sentido, o período do pós-guerra (décadas de 1950 e 1960) caracterizou-se pelo robusto crescimento da economia capitalista não só na Venezuela como ao redor do mundo. Não por acaso, durante boa parte da "bonança petroleira", costumava-se apontar a Venezuela como a mais promissora democracia latino-americana ${ }^{3}$.

De fato, com o re-estabelecimento da democracia formal em 1958, através do Pacto de Punto Fijo ${ }^{4}$ os venezuelanos gozaram de um regime democrático aparentemente estável, com eleições regulares e alternância partidária no poder. Nesse ínterim pouco se questionou o protagônico papel exercido pela administração pública no fomento do capitalismo no país. O Estado, possuidor das jazidas de petróleo e principal administrador das riquezas por estas produzidas, assumiu as rédeas do desenvolvimento sócio-econômico venezuelano. $\mathrm{O}$ tamanho das estruturas estatais venezuelanas assumiam, assim, gigantescas proporções: 
Transformar o gigante num pigmeu...

Venezuela es una de las economías más estatistas del hemisferio occidental, según un conocido intelectual venezolano [Moisés Naim, diretor da revista 'Foreign Politcs'], 'la mas estatizada fuera del mundo comunista'. Ese ha sido el fundamento del modelo de desarrollo económico, social y político, históricamente conformado por la confluencia de una economía petrolera en manos del Estado, en un marco democrático representativo con partidos de fuerte componente populista. (PETIT, 2006, p. 03).

Como consequência do elevado acúmulo de divisas gerado pela crise energética de 1973, que catapultou os preços do petróleo em quase $400 \%$, a grave crise econômica que afetou grande parte da América Latina já no início da década de 1970 chegou ao país com certo atraso. Porém, o castelo de areia não demoraria a ruir. Os perniciosos efeitos gerados pela extrema dependência em relação ao comércio petroleiro, já no início da década de 1980, tornaram-se incontroláveis:

El Estado se convirtió en el gran empleador creando una aberrante dinámica de endeudamiento para pagar los gastos de funcionamiento de la administración pública, cuyo monto, sólo por servicio de la deuda llegó a representar un tercio del presupuesto. En una situación solo comparable a la de los países árabes, por la propiedad estatal del petróleo, el 90\% de los ingresos en divisas internacionales han estado bajo control estatal, cosa que no ha ocurrido en ningún país del mundo (PETIT, 2006, p. 05-06).

Nesse sentido, o último ano de governo do presidente Luís Herrera Campins (1979-1983) representou o marco inicial do colapso econômico e institucional que assolou o país no quarto final do século XX. Segundo López-Maya (2005, p.45), os resultados da desaceleração econômica, rapidamente, fizeram-se sentir no campo político, uma vez que os mecanismos de mediação entre estado e sociedade, tais como os sindicatos e a igreja, passaram a apresentar sistemáticas dificuldades em cumprir as funções de manutenção do 
consenso político a elas atribuídas pelo Pacto de Punto Fijo. As tensões entre classes, até então amortecidas pela precária, porém eficiente, distribuição dos abundantes recursos petroleiros, se mostravam cada vem mais fortes.

Em meio à profunda recessão econômica Jaime Lusinchi assumiu a presidência da República para o período entre 1984-1989. Poucos meses após sua posse, o presidente anunciou um pacote de ajustes econômicos em consonância com as recomendações emanadas das agências financeiras internacionais, embora este não fosse, formalmente, um plano derivado de acordo firmado com o Fundo Monetário Internacional (FMI). Era, sim, um compromisso unilateralmente assumido pelo governo venezuelano que, através dessa atitude, procurava criar condições favoráveis ao renegociamento da dívida externa nacional para obter melhores possibilidades de retomar ao crescimento econômico estagnado desde meados da década de 1970.

Conforme relata Lucena (1990, p. 157), os principais procedimentos colocados em prática pela administração Lusinchi pautavam-se pela desvalorização do bolívar, o aumento no preço dos combustíveis e uma série de recomendações para reduzir os gastos relativos ao funcionamento do Estado. Em contrapartida, simultaneamente, foram anunciadas providências que não eram compatíveis com um programa neoliberal ortodoxo, como o provimento de medidas compensatórias para minorar o impacto do ajuste na remuneração dos trabalhadores e o pagamento de dívidas internas da administração pública.

Já em dezembro de 1988, em meio a mais uma das recorrentes crises deflagradas pela desvalorização nos preços do petróleo, Lusinchi, novamente, recorreu à desvalorização da moeda para tentar equilibrar a deficitária balança de pagamento do país. Contudo, ao contrário do que se poderia imaginar, tal medida não significou a ampliação do ajuste neoliberal. Pelo contrário. Esta foi uma cartada dada pelo governo para expandir os gastos fiscais do Estado e revertê-los em políticas sociais com o claro objetivo de garantir sua popularidade e assegurar, assim, o triunfo eleitoral puntofijista nas eleições presidenciais marcadas para o início do próximo ano. Tal atitude, de acordo com Parker (2003, p. 90), resultou na diminuição 
Transformar o gigante num pigmeu...

excessiva das reservas internacionais da nação o que, somado a outros graves desequilíbrios macroeconômicos, levou o presidente, em janeiro de 1989, a declarar moratória ao pagamento da dívida externa.

\section{Carlos Andrés Pérez: o trator neoliberal (1989-1993)}

A primeira opção encontrada pelo establishment venezuelano para tentar amenizar as profundas feridas causadas pela depressão econômica foi recorrer ao principal ícone do período dourado que o país há pouco experimentara. Carlos Andrés Perez (CAP), que havia sido o presidente da república entre 1974 e 1979, era tido como o mais bem preparado político que o país havia produzido durante toda sua história ${ }^{5}$.

Em 16 de fevereiro de 1989, depois de cercar-se por um contingente de jovens economistas seguidores da Escola de Chicago e poucos dias após o início de seu mandato, o presidente, sem ao menos consultar o Congresso Nacional ou debater o assunto durante a campanha eleitoral, anunciou um amplo e drástico programa de ajuste para o país. O novo mandatário argumentara que os principais indicadores sociais e econômicos herdados da administração Lusinchi eram tão alarmantes que requeriam uma guinada de grandes proporções no modelo de desenvolvimento nacional.

Segundo a agenda de Pérez era imperioso rever o papel e o tamanho do Estado venezuelano que, durante meio século, havia controlado a vida política e econômica nacional. Em suas palavras, reproduzidas por Gott $(2004$, p. 80$)$, "o ideal seria reduzir as atividades estatais a sua expressão mínima”. Ou seja, para dizer o mínimo a missão assumida por CAP era dificílima: fazer encolher ao máximo as então superdimensionadas estruturas do Estado venezuelano para, assim, reduzi-lo ao menor tamanho possível, tal qual um pigmeu.

Para tanto, com a alcunha de "A Grande Virada", o presidente impôs uma série de modificações econômicas, fiscais e monetárias que assumiam a necessidade de, num primeiro momento, reparar os prejuízos latentes e estabilizar as finanças do Estado para, em seguida, lançar as bases de uma mudança estrutural na economia do país. Tal modificação seria pautada, essencialmente, pela outorga 
do papel preponderante às forças da iniciativa privada na condução do processo econômico. Era o preço a ser pago pelo empréstimo de U\$ 4,5 bilhões recém-adquirido junto ao FMI.

Assim, de maneira oposta ao compromisso assumido por Lusinchi pouco mais de três anos antes, o novo programa de ajuste abruptamente anunciado por CAP era resultado direto das recomendações feitas pela missão do Fundo Monetário enviada à Venezuela em 1987. Por conseguinte, os ajustes anunciados pelo mandatário seguiam com exatidão as recém elaboradas recomendações do Consenso de Washington $(\mathrm{CW})^{6}$ : restrição dos gastos fiscais do Estado; restrição dos níveis salariais; estabelecimento das taxas de juros pelo mercado; redução dos subsídios às atividades agrícolas; ajuste das tarifas dos bens e serviços oferecidos pelas empresas estatais, incluindo os preços dos produtos derivados do petróleo no mercado interno (faz-se necessário mencionar que, mesmo tendo sido reajustado, o valor cobrado pelo combustível no país continuou a ser simbólico tamanho era o subsidio prestado pelo governo) ${ }^{7}$.

As metas do programa eram, nesse sentido, extremamente claras: a partir do protagonismo do grande empresariado nacional e do capital transnacional, flexibilizar a economia de modo a vincular a sociedade venezuelana junto à competição dos mercados internacionais globalizados.

À parte das modificações macroeconômicas de praxe, o mais importante ponto da agenda neoliberal desenhada por Pérez dizia respeito ao início de um movimento que vislumbrava a abertura da exploração e comércio petroleiro por entes da iniciativa privada. A intenção não era privatizar a PDVSA, o que seria um imenso contrasenso, uma vez que fora exatamente CAP o presidente responsável pela nacionalização da empresa em 1976. O que se propugnava era a facilitação para o ingresso de investimentos estrangeiros nas variadas atividades produtivas relacionadas ao combustível. Além disso, buscava-se, paulatinamente, a desregulamentação do setor para fins de diminuição da carga tributária e do repasso de royalties ao Estado.

A análise dos resultados quantitativos imediatos que seguiram a implantação da "Grande Virada" é clara e aponta para uma forte recessão expressa, segundo os índices extraídos do estudo de Lander (2006, p. 17), pela redução do PIB em 8,7\% no ano de 
Transformar o gigante num pigmeu...

1989 e, especialmente, pela alta histórica dos níveis inflacionários que eram de 29,49\% em 1988 e passaram a 84,46\% em 1989. A taxa de desemprego também aumentou consideravelmente subindo, no mesmo interregno, de 6,9 para 9,6\%, o que representou um total de aproximadamente 200 mil pessoas desempregadas num intervalo de apenas um ano. Por outro lado, graças à severa contração na economia, tanto a balança de pagamentos quanto a balança comercial se fizeram positivas, recuperando, assim, parte das reservas internacionais.

Se os efeitos dos ajustes impostos por Pérez não se mostraram satisfatórios no campo macroeconômico pode-se afirmar que no contexto social os resultados foram catastróficos. A prova do profundo descontentamento da sociedade venezuelana em relação à "Grande Virada" veio logo na manhã em que se colocaram em prática os ajustes neoliberais, mais precisamente em 27 de fevereiro de 1989, data marcada pelo advento da mais feroz e sangrenta rebelião popular já ocorrida na história venezuelana.

Estudantes, camelôs e operários, ao se darem conta que as tarifas do combustível haviam dobrado e a do transporte público aumentara em 30\% tomaram o principal terminal rodoviário da cidade de Guarena, localizada na periferia de Caracas, e iniciaram um protesto contra a majoração das tarifas. Poucas horas depois, a manifestação havia se espalhado pelas principais avenidas na capital e interior do país.

Foi somente na tarde seguinte, quando o levante tomara proporções ainda maiores, que CAP declarou estado de sítio em todo território nacional. A partir daí, a repressão passou a ser brutal. O terror generalizou-se e, de acordo com os números divulgados pelo governo, 277 pessoas foram sumariamente assassinadas por estarem nas ruas depois do toque de recolher decretado pelo presidente ${ }^{8}$. Este foi o Caracazo, a primeira revolta popular contra o capitalismo neoliberal, antecedendo os famosos protestos ocorridos em Seattle (EUA) em uma década.

Os desdobramentos da revolta urbana, tanto entre a população que, de forma anárquica e abrupta, sublevou-se quanto entre os membros do exército envolvidos na repressão, teria forte impacto sobre a dinâmica política nos anos seguintes. Muitos estudos - entre 
os quais se destaca o trabalho de Gott (2004) - apontam esse acontecimento como o marco inicial da história contemporânea no país, uma vez que implodiu as bases do sistema hegemônico e evidenciou a fratura existente entre as classes sociais dominantes, ou seja, a direção intelectual, econômica e política da sociedade e as classes subalternas, insatisfeitas por terem de, sozinhas, pagar os prejuízos causados por décadas de corrupção e péssima administração pública.

Entretanto, também ficou claro que as manifestações careciam de organização, fato que as impediu de gerar transformações políticas imediatas. Tal cenário seria modificado com a ascensão política do Movimento Bolivariano Revolucionário-2009 agrupamento militar comandado por Hugo Chávez Frias que, três anos depois, apresentar-se-ia ao país ao tentar, por duas vezes, derrubar Pérez do poder.

Mesmo seriamente abalada pelos desdobramentos do Caracazo, a administração neoliberal de Pérez não retrocedeu. Segundo Lander (2006, p. 32), a partir de 1990 as finanças do país deram sinal de recuperação, registrando-se um aumento no PIB de 6,47\%, seguido por outro salto de $9,73 \%$ no ano de 1991. A dívida externa foi renegociada com os organismos financeiros internacionais e se colocaram em dia os pagamentos pendentes. Novos empréstimos foram efetuados pelo Estado, realizando-se investimentos em setores deficitários e, assim, conseguiu-se amenizar a fuga de capitais.

Não obstante, o fortalecimento dos indicadores macroeconômicos não se prolongou de forma sustentável. Já em 1992 se reverteu boa parte dessas conquistas. $\mathrm{O}$ incremento do PIB percebido no biênio anterior só foi possível graças à recuperação natural das perdas ocorridas anteriormente e, também, pelo considerável aumento dos gastos públicos e novos endividamentos por parte do Estado.

Talvez o único objetivo estabelecido por CAP que conseguiu ser plenamente alcançado pela "Grande Virada" foi, não por acaso, a geração de capacidade financeira para o pagamento da dívida externa. Graças à política econômica notadamente recessiva e a consequente diminuição do consumo no mercado interno foram geradas reservas financeiras excedentes que permitiram cumprir com os compromissos internacionais recém negociados. A preocupação central estabelecida pelo CW fora sanada. 
Transformar o gigante num pigmeu...

Como se não bastasse o caos gerado pelo desgaste social oriundo dos efeitos do Caracazo e a total ineficácia das medidas econômicas adotadas pela "Grande Virada", o governo CAP teve de enfrentar, ainda, duas importantes sublevações da Força Armada Nacional. A primeira, ocorrida em 3 de fevereiro de 1992, foi capitaneada pelo então tenente-coronel Hugo Chávez Frias e contou com a adesão de aproximadamente $10 \%$ do contingente do exército que se organizaram em torno do objetivo de prender Pérez e fazê-lo renunciar. Os militares insurrectos não obtiveram sucesso e Chávez, juntamente com outros 180 oficiais, acabou preso. Pouco mais de um semestre depois, em 27 de novembro, o MBR-200, agora sob as ordens do vice-almirante da Marinha Hernán Grüber Odréman, tentou novamente derrubar Pérez, falhando mais uma vez ${ }^{10}$.

Os militantes do MBR-200, apesar de não terem alcançado o objetivo ao qual se propuseram, desferiram outro duro golpe ao já combalido governo de CAP. Apoiando-se num voraz discurso contra as medidas econômicas impostas pelo FMI, os bolivarianos saíram politicamente vitoriosos, uma vez que as pesquisas de opinião efetuadas pouco após os acontecimentos davam conta de que aproximadamente $60 \%$ dos venezuelanos eram simpáticos ao mal sucedido levante, conforme atesta o estudo de López-Maya (2005, p. 110).

Pela primeira vez em quatro décadas uma organização política apresentou-se como uma sólida alternativa ao regime puntofijista. $\mathrm{O}$ golpe de misericórdia ao governo CAP veio quando um escândalo político provocado por rumores de que o presidente havia desviado cerca de U\$ 17 milhões foi denunciado pelo seu próprio partido perante a Suprema Corte de Justiça. No dia 5 de maio de 1993 o tribunal considerou que havia evidências suficientes para afastá-lo do cargo. Além do impeachment, a Pérez foi imposta a pena 23 meses de prisão domiciliar. Era, oficialmente, o fim do puntofijismo. 


\section{Rafael Caldera: ruptura transformada em continuísmo (1993-98)}

Em junho de 1993, um governo de emergência chefiado por Ramón Velásquez foi designado para cumprir o restante do termo constitucional. Eleições foram convocadas para o final do ano e dela saiu vencedor Rafael Caldera com 30,46\% dos votos.

A campanha eleitoral levada a cabo por Caldera foi construída de forma a afastá-lo ao máximo do discurso e das ações que caracterizaram o governo CAP. Em especial, o então candidato fez questão de rechaçar a opção de, caso eleito, voltar a pedir financiamentos junto ao FMI. Prova disso é sua "Carta de Intensión al Pueblo de Venezuela"11, redigida pouco antes do pleito, na qual Caldera se comprometeu a evitar novas privatizações e a renegociar a dívida externa de maneira enérgica. Consequentemente, dada a imperiosidade das afirmações feitas por Caldera, faz-se notório o fato de seu triunfo ser, também, reflexo do extenso sentimento de crítica e falta de apoio por parte dos venezuelanos às medidas ortodoxas de caráter neoliberal.

O presidente, uma vez empossado, colocou em prática o chamado "Programa de Estabilización e Recuperación Económica", idealizado para servir como transição entre o sistema neoliberal legado do governo CAP e um novo modelo de desenvolvimento econômico a ser implantado respeitando as prioridades supracitadas ${ }^{12}$.

De fato, durante seus primeiros 18 meses, a nova administração adotou medidas que se colocavam em desacordo com os preceitos estabelecidos pelo CW como, por exemplo, o controle estatal do câmbio, dos preços e das taxas de juros, além da postergação do aumento nos preços dos combustíveis. De acordo com Ellner (1998, p. 02), tais opções causaram grande desconforto entre o governo e o empresariado local que acusou a Caldera de, irresponsavelmente, autopromover sua administração a partir do uso de um repaginado "populismo econômico".

A essas críticas que, sem dúvida, desestabilizaram politicamente o governo seguiu-se uma crise do sistema bancário nacional, causando prejuízos a já combalida economia venezuelana. Os reflexos do chamado "Efeito Tequila", que colapsou a economia mexicana em 
Transformar o gigante num pigmeu...

1994, atingiram em cheio o país. Para evitar a quebradeira bancária, empréstimos estrangeiros e fundos de créditos nacionais, estes obtidos através da majoração da carga de impostos e dos lucros advindos de privatizações ${ }^{13}$, foram utilizados. Segundo Ali (2006, p. 78), em apenas um ano, não menos de $12 \%$ do total do Produto Interno Bruto, cerca de U\$ 5,6 bilhões, foram consumidos para evitar a bancarrota de dez bancos.

Os efeitos dos distúrbios acima descritos culminaram na desaceleração da atividade econômica e em altos índices inflacionários que, em 1996, bateram a casa dos 103\%. Assim, em março, Rafael Caldera se viu obrigado a modificar substancialmente seu plano de governo e, após substituir grande parte de sua equipe ministerial, apelou ao FMI. Pela segunda vez em menos de sete anos um mandatário venezuelano, de pires nas mãos, clamava por socorro na capital estadunidense.

Num contexto político bastante distinto daquele experimentado durante o governo CAP, uma vez que, agora, importantes setores da sociedade pressionavam pela redefinição da política econômica, o presidente Caldera apresentou à nação a "Agenda Venezuela", o novo programa de ajuste macroeconômico concebido em conformidade ao neoliberalismo ortodoxo: através de ajustes fiscais e cortes nos investimentos públicos, houve drástica redução dos gastos e investimentos estatais; facilitou-se a especulação e o mercado de capitais ao, progressivamente, baixar a taxa de juros; já em sua política fiscal, efetuou-se uma reforma tributária como mecanismo para, ao elevar a arrecadação interna, evitar o déficit público; finalmente, através da reforma e flexibilização da legislação trabalhista reduziu-se o pagamento dos encargos trabalhistas relativos à demissão de trabalhadores sem justa-causa (LANDER, 2006, p. 58). Interessante ressaltar que, após onze anos de administração bolivariana, ainda não houve modificações substanciais da legislação trabalhista referente a este último ponto.

Dessa forma, resta claro que as principais diferenças entre a "Grande Virada" e a "Agenda Venezuela" não são de ordem estrutural. Elas se encontram, sim, no campo político, uma vez que Rafael Caldera, mediante hábeis acordos partidários, conseguiu costurar entre os setores sociais uma conjuntura política menos turbulenta 
do que a experimentada durante os tempos de CAP. Tal arranjo foi possível graças a aposta feita por Caldera em adotar políticas assistenciais compensatórias, especificamente os chamados "Programas sociales contra la pobreza"14, os quais apaziguaram as tensões e contradições sociais naturalmente geradas pelo ajuste econômico.

Apesar das "contraprestações sociais" é interessante destacar a correlação entre o número de protestos violentos ocorridos no país e o período subseqüente à adoção das medidas de corte neoliberal, tanto por parte de Pérez como por parte de Caldera:

Llama la atención como las reseñas de protestas violentas, que en los primeros años de la serie [1983 até 1986] constituían menos de 10\% del total, desde 1987 pasan a tener siempre porcentajes de dos dígitos. Se registran como períodos especialmente violentos los períodos 91-92 y 92-93, correspondientes a la crisis política del segundo gobierno Pérez, y el período 95-96. Este segundo período corresponde a los años de aplicación del programa de ajuste macroeconómico conocido como la 'Agenda Venezuela'(LÓPEZ-MAYA, 2005, p. 91-92).

Outra relevante modificação instituída pela "Agenda Venezuela" foi a chamada "Apertura Petrolera". Através dela instituiu-se um agressivo programa de transferências do setor público para o setor privado das atividades relativas à prospecção, refinamento e comercialização do combustível. Mesmo sendo notória a grave crise social que deixava $66,7 \%$ dos venezuelanos abaixo da linha de pobreza, o próprio governo propôs reduzir o valor do imposto pago pelas empresas petroleiras multinacionais a titulo de royalties dos $16 \%$ previstos em lei para irrisórios 1\%. O Congresso venezuelano aprovou as linhas mestras da abertura e, já em 1996, 8 contratos foram assinados com empresas estrangeiras para a exploração privada de campos inativos ou marginais no país ${ }^{15}$.

Ademais, a "Apertura Petrolera" influenciou no novo posicionamento assumido pela Venezuela junto à Organização dos Países Exportadores de Petróleo (OPEP), uma vez que o governo Caldera posicionou-se favoravelmente à regulamentação dos preços como 
Transformar o gigante num pigmeu...

resultado direto da atuação do mercado internacional, sem que fosse necessária a interferência das nações exportadoras. Mesmo sem a anuência dos demais países membros, e desrespeitando as cotas previamente assumidas perante a organização, a Venezuela expandiu em grande medida suas exportações diárias, causando graves tensões diplomáticas na organização multilateral.

Em que pese, no princípio, a resistência popular à "Agenda Venezuela" ter sido mais amena do que a enfrentada pela "Grande Virada" de CAP, a brusca queda nos preços internacionais do petróleo, a partir de outubro de 1997, causou profundos abalos ao governo de Rafael Caldeira. Vale ressaltar que o papel da "Apertura Petrolera" foi determinante para a diminuição do ingresso de divisas na Venezuela, tendo em vista o posicionamento do país que, ao aumentar substancialmente a produção do combustível, causou o incremento da produção mundial o que, conseqüentemente, culminou na queda dos preços no mercado internacional. Segundo Baptista (2005, p. 107), entre 1989 e 1998, a produção petroleira venezuelana teve um aumento substancial na ordem de $91 \%$, passando de 1,7 para 3,3 milhões de barris/dia. Projeções estabelecidas pela PDVSA dão conta de que aproximadamente um terço do total da produção entre 2004 e 2009 ocorreu em campos inaugurados pelo programa de abertura petroleira.

Com base nos levantamentos até aqui apresentados pode-se afirmar que os resultados sócio-econômicos obtidos pelo governo Rafael Caldera estiveram longe do aceitável. O relatório anual de 1996 elaborado pelo "Programa Venezolano de Educación-Acción en Derechos Humanos (PROVEA) ${ }^{16 "}$ é bastante contundente em sua análise sobre o desempenho do governo Caldera em relação às suas políticas sociais:

El gasto social correspondiente a 1995, en términos reales, per cápita, es inferior al que se dedicó a ese fin en 1984 y equivalente a 1989, un año crítico en la historia del país. Luego del incremento ocurrido durante los años 1990-92 el gasto social ha experimentado una fuerte caída Una vez más, el gobierno Caldera no solo no ha frenado la disminución en la asignación de los gastos sociales, sino que incluso ha 
optado por reducirlo. La llamada Agenda Venezuela dedica solo uno de sus diez puntos al aspecto netamente social. Según cifras del Ministerio de la Familia, los programas sociales representan ahora apenas el $1 \%$ del presupuesto nacional.

Ademais, o desemprego e a pobreza mantiveram a tendência ascendente, registrando-se o total de 48,33\% de domicílios abaixo da linha de pobreza, sendo que $27,66 \%$ deles encontravam-se em situação de pobreza extrema. Os estudos de López-Maya e Lander (2000, p. 193) apontam que, no setor produtivo, $48,20 \%$ dos trabalhadores não desempregados encontravam-se na informalidade. A inflação acumulada entre o período entre 1994-1998 atingiu a cifra de $885 \%$.

Concomitantemente, graças à desregulamentação das políticas concernentes ao movimento de capitais, percebeu-se a instalação de grande volume de investimentos financeiros de curto prazo no país. Estes, por sua vez, lograram atrair capitais especulativos para viabilizar a sobrevalorização artificial do câmbio, uma das principais metas assumidas por ocasião do acordo assinado com o FMI. Em decorrência desses fatos, a Venezuela tornou-se um porto receptor de capitais estrangeiros. Porém, ínfima parcela destes, efetivamente, vinculava-se à produção de bens e serviços.

As referências quantitativas acima elencadas constituem uma expressão palpável da situação de grave deteriorização social vivenciada no país durante o final da década de 1990. Não se pretende, com a interpretação das consequências advindas do ajuste neoliberal, sugerir que não havia necessidade de se promover profundas mudanças institucionais ou remediar a constante instabilidade que historicamente assolou a peculiar economia venezuelana. É nítido que os perniciosos reflexos culturais advindos da mentalidade rentista são demasiado fortes e, indubitavelmente, contribuem tanto para o estabelecimento de um Estado paternalista como para se incutir na prática social a idéia de que as demandas populares só serão solucionadas quando forem intermediadas pelo aparelho estatal. Parece óbvio que encontrar uma alternativa simples para problemas 
Transformar o gigante num pigmeu...

tão complexos não é tarefa de fácil execução. Nessas condições não há política econômica que, por si só, apresente as soluções para todos os problemas.

Contudo, como já foi feito, não se pode deixar de apontar as debilidades do projeto neoliberal imposto aos venezuelanos. A desordem econômica patrocinada pelo $\mathrm{CW}$ afetou profundamente o desenvolvimento social do país, fazendo com que áreas essenciais como educação e saúde fossem relegadas a segundo plano, enquanto bilhares de dólares eram entregues a banqueiros falidos e a políticos corruptos.

A massiva, e por vezes, violenta mobilização por parte dos setores sociais menos abastados atesta a fragilidade do modelo de desenvolvimento adotado pelo país no decorrer dos anos 90. Sem sombra de dúvidas, os acontecimentos que estariam por vir - a ascensão bolivariana ao ápice do sistema político nacional - foram extremamente marcados por essa conjuntura e, por isso, devem ser explicados a partir desse contexto.

\section{Considerações finais}

A breve compilação histórica aqui exposta nos mostra que a Venezuela foi integrada à investida neoliberal da década de 1990 por meio da atuação de uma classe social hegemônica em crise que, ao se dar conta da irreversível falência do rentismo, achou por bem aliar-se ao FMI e, assim, ser complacente com os desenhos estratégicos delineados pelo CW. O país, por sua vez, foi um dos principais alvos da nova fase de (sub)desenvolvimento capitalista, pois sua principal fonte (a economia dos EUA) é, historicamente, dependente do combustível venezuelano ${ }^{17}$. A confluência desses interesses fez com que a nação, apesar da resistência popular e das características superdimensionadas das estruturas estatais, paradoxalmente caminhasse a paços largos em direção ao Estado mínimo e à economia de mercado.

López-Maya (2005, p. 104) postula que os desastrosos resultados gerados por tal escolha, comprovados pelos indicadores sócio-econômicos obtidos pelo país durante a década de 1990, 
explicam-se, segundo os que apoiaram sua implementação, pela não manutenção sustentável das políticas de ajuste macroeconômico, constantemente interrompidas ora por manifestações populares ora pelas trocas de governos.

Por outro lado, é nítida a resistência política que importantes frações da sociedade venezuelana (notadamente os setores de classe média-baixa e baixa) apresentaram ante a imposição do modelo de desenvolvimento pautado pela orientação neoliberal. A sucessão de experiências desastrosas, segundo a análise de López-Maya e Lander (2000, p. 188), nos permite encarar o país como um típico exemplo de nação com 'fadiga de ajuste', expressão utilizada para classificar determinada sociedade que, pelas tentativas reiteradamente frustradas, perde a confiança na capacidade do projeto neoliberal em servir como solução para crises financeiras e/ou institucionais.

Não obstante, os mencionados fracassos das políticas de ajuste econômico e a impossibilidade de instrumentalizar, por meio delas, programas exitosos de reestruturação do desenvolvimento nacional acentuaram de maneira determinante a crise institucional há muito instalada no país.

Tal situação reforçou tendências à deteriorização social e às mudanças políticas drásticas. Nesse sentido, fortemente influenciada pela penúria econômica, a conjuntura venezuelana mostrou-se perfeita para, no ano de 1998, alavancar a candidatura de Hugo Chávez Frias à presidência da república, uma vez que suas críticas ao neoliberalismo contribuíram de maneira decisiva para re-colocar os assuntos relativos ao modelo de desenvolvimento no centro do debate nacional. O programa de governo chavista expressamente declarou fora do alcance do capital privado os setores estratégicos da nação, entre os quais a tecnologia militar e a exploração dos hidrocarbonetos.

A oratória apresentada pelo então candidato era extremamente clara: "Sin una transformación a fondo de las estructuras del Estado y del sistema político venezolano, no hay posibilidades de impulsar un proceso realmente productivo de desarrollo económico y social (VENEZUELA, 1999, p. 37)". Muito por conta desse tipo de proposta, comprometida com o que os bolivarianos chamaram de "refundação do Estado", 3,67 milhões de cidadãos (cifra que 
Transformar o gigante num pigmeu...

representou $56,2 \%$ do total de votos válidos) elegeram a Hugo Chávez Frías o $53^{\circ}$ presidente da Venezuela.

Turning the giant into a pygmy: the misadventures of the neoliberal project in Venezuela (1989-1998)

Abstract. The article provides an overview of the major political events that marked the Venezuelan society during the 1990s. The analysis rests on the governments of Carlos Andrés Pérez (1989-1993) and Rafael Caldera (1993-1998) in which efforts were made to link the country to the neoliberal model of development. The circumstances that led to the complete failure of the economic adjustment programs implemented by both governments - "La grande viraje" e "Agenda Venezuela", respectively - influenced decisively in the fulminant rise of the "bolivarian political project" on the national elections in late 1998.

Keywords: Venezuela. Neoliberalism. 1990s.

\section{Notas}

${ }^{1}$ Tais dados, bem como outros índices macroeconômicos são encontrados no sítio http://indexmundi.com/pt/venezuela/produto_interno_bruto_(pib).html. ${ }^{2} \mathrm{O}$ mencionado modelo de desenvolvimento caracteriza-se, essencialmente, pela extrema dependência do setor petroleiro. Segundo o texto de Silva Barros (2006, p. 212), a partir da década de 1970 , não menos de $75 \%$ do total das exportações venezuelanas advém do comércio internacional do petróleo, valor que corresponde à metade do montante total arrecadado pelo Estado em impostos. Dessa maneira, grandes partes do ingresso fiscal provem de um setor pouco integrado da economia, cuja rentabilidade se deve ao pagamento de royalties ao Estado e, não propriamente, à vitalidade do setor produtivo nacional.

${ }^{3}$ Nas palavras de Buxton (2001, p. 02): "Venezuela was traditionally viewed as bedrock democratic stability in a region otherwise cursed by military intervention and political underdevelopment".

${ }^{4}$ A coalizão capitaneada pelos partidos "Acción Democrática" (AD) e "Partido Socialcristiano" (COPEI) tinha como principal objetivo a definição de uma agenda que reduzisse as diferenças programáticas de modo a estruturar um programa de governo comum que abarcasse, concomitantemente, as expectativas e planos políticos das duas agremiações partidárias. Assim, estabeleceu-se um amplo e hegemônico consenso entre as mais importantes instituições do país, incluindo os sindicatos patronais e dos trabalhadores, a igreja, as Forças Armadas e outras entidades civis que garantiam, na prática, a estabilidade política da nação.

Anos 90, Porto Alegre, v. 17, n. 32, p. 137-157, dez. 2010 


\section{Pedro Henrique de Moraes Cícero}

${ }^{5} \mathrm{O}$ primeiro mandato presidencial de CAP notabilizou-se pelo ótimo desempenho da economia e, principalmente, pela nacionalização de todos os poços de prospecção de petróleo, fato que culminou na criação da gigante estatal PDVSA. Essa ousadia foi sustentada pela conjuntura econômica favorável que dava ao país certa autonomia frente aos interesses estrangeiros. Em várias ocasiões, a partir da utilização de discursos combativos, Pérez enfrentou o Banco Mundial, descrevendo os seus economistas como 'genocidas a serviço do totalitarismo econômico’. De acordo com Ali (2008, p.69), a retórica era popular, mas foram as nacionalizações da Shell e da US Steel que lhe garantiram o massivo apoio dos venezuelanos.

${ }^{6}$ As políticas neoliberais colocadas em prática na América Latina, assim como em outros países com alto endividamento externo, durante os anos de 1990 ficaram conhecidas como o "Consenso de Washington". Este consistia num programa de dez pontos com o objetivo principal de reformar os mecanismos internos de regulamentação econômica das nações, de tal forma a dar-lhes condições para pagar as dívidas que haviam contraído. Entretanto, na prática, as exigências feitas aos devedores constituíam praticamente uma nova forma de colonialismo, tamanho os benefícios que o programa neoliberal garantia aos credores, estadunidenses em sua maioria. A Venezuela acumulara uma enorme dívida, imprudentemente adquirida a juros altíssimos por sucessivos governos, o que fez deste país um alvo privilegiado das reformas propostas pelo Consenso de Washington.

${ }^{7}$ Para maiores detalhes sobre as medidas anunciadas por Carlos Andrés Pérez consultar o texto integral "Lineamientos del VII Plán de la Nación” disponível no sítio http:/ /www.worldcat.org/oclc/23833593.

${ }^{8}$ Os números relativos ao massacre fornecidos pela administração pública foram amplamente contestados. Outros levantamentos foram efetuados e, naquele que é considerado o mais preciso deles, o número total de fatalidades chegou a 396 (LÓPEZ-MAYA, 2005, p. 75).

${ }^{9}$ Grupo constituído no seio das Forças Armadas da Venezuela, fundado em 1982 e dirigido por Chávez e outros dois militares [Felipe Acosta e Jesús Urdanera Hernández]. A partir da metáfora da "árvore das três raízes" [expressão utilizada pelo grupo para designar suas três grandes referências: Simon Bolívar, Ezequiel Zamora e Simon Rodriguez] o MBR-200 estruturou uma célula política no interior do exército que, durante duas décadas, organizou-se para fomentar um golpe revolucionário para por fim ao Regime puntofijista.

${ }^{10}$ Para maiores detalhes sobre a constituição do MBR-200 e das duas malogradas tentativas de golpe de Estado arquitetado por Chávez e seus companheiros de armas consultar Gott (2004) e Harnecker (2004).

${ }^{11} \mathrm{O}$ documento pode ser lido na íntegra em: http://members.ziggo.nl/gda1/ caldera.html. 
Transformar o gigante num pigmeu...

${ }^{12} \mathrm{O}$ documento pode ser lido na íntegra em: http://www.hoy.com.ec/noticiasecuador/nuevo-plan-en-venezuela-28624-28624.html.

${ }^{13}$ Tais recursos eram provenientes das privatizações de empresas públicas como, por exemplo, a companhia nacional de telefonia (Cantv), o sistema nacional de portos, a companhia aérea "Viasa", além de seis instituições bancárias nacionais sete centrais açucareiras e algumas empresas do setor alimentício.

${ }^{14}$ Segundo o estudo de Alvarado Chacin (2003, p. 437) a principal característica das políticas sociais implantadas pelo governo Rafael Caldera é seu crescente financiamento/dependência das organizações não governamentais e das agências financeiras internacionais e a concomitante deteriorização dos serviços sociais prestados pelo Estado. Nesse sentido, em função das relações entre as medidas de ajuste macroeconômico e o contrapeso de seus profundos custos sociais, priorizaram-se as debilidades de curto prazo. Reservou-se à política social, assim, um papel compensatório ao privilegiar apenas setores "cruciais" tais como educação, saúde e nutrição. Por outro lado, os outros braços da política social como, por exemplo, a formação profissional e a seguridade social, perderam importância como áreas de atenção.

${ }^{15}$ Dados obtidos em: http://www.beg.utexas.edu/energyecon/newera/case_studies. ${ }^{16}$ Dados obtidos em: http://www.derechos.org.ve/publicaciones/infanual/1995_96. ${ }^{17}$ Ao consultar o relatório do "Center for Energy Economics", instituição de pesquisa e estudos de casos vinculados ao governo norte-americano, percebe-se a magnitude dessa dependência: no ano de 2002 , somente $16 \%$ da produção petroleira venezuelana foi consumida internamente, sendo que os outros $84 \%$ foram exportados. Dessas exportações, aproximadamente $62 \%$ dirigiram-se aos Estados Unidos. A Venezuela, juntamente com Canadá, México e Arábia Saudita, são os quatro maiores exportadores de combustível para os norte-americanos, sendo que $13 \%$ do total de exportações da maior potência econômica mundial originam-se da Venezuela.

\section{Referências}

ALI, Tariq. Piratas do Caribe. Rio de Janeiro: Record, 2008.

ALVARADO CHACIN, Neritza. Pobreza y asistencialismo en Venezuela. Revista de Ciencias Sociales. v. 9, n. 3, p. 431-458, 2003.

BAPTISTA, Asdrúbal. El capitalismo rentístico: elementos cuantitativos de la economía venezolana. Cuadernos del CENDES. Caracas, Ano 22, n. 60, p. 95111, 2005.

Anos 90, Porto Alegre, v. 17, n. 32, p. 137-157, dez. 2010 


\section{Pedro Henrique de Moraes Cícero}

BUXTON, Julia. The failure of political reform in Venezuela. Burlington: Ashgate, 2001.

ELLNER, Steve. Izquierda y política en la agenda neoliberal venezolana. Revista Nueva Sociedad, n. 157, p. 125-136, 1998.

GOTT, Richard. À Sombra do Libertador. São Paulo: Expressão Popular, 2004.

HARNECKER, Marta. Hugo Chávez Frías, um homem, um povo (entrevista). São Paulo: Expressão Popular, 2004.

LANDER, Edgardo. Neoliberalismo, Sociedad Civily Democracia. Caracas: Universidad Central de Venezuela, 2006.

LÓPEZ-MAYA, Margarita. Del viernes negro al referendo revocatorio. Caracas: Alfandil, 2005.

LUCENA, Héctor. La flexibilización neoliberal en Venezuela. Revista Nueva Sociedad. Caracas, n. 110, p. 152-159, 1990.

PETIT, Maibort. La crisis vista desde las debilidades de la sociedad civil venezolana frente al Estado. Caracas, 2006. Texto disponível em: http://analistaslibres.com/PDF/ Crisis-Deb-x-MP.pdf. Acesso em 12 de ago. 2010.

SILVA BARROS, Pedro. Chávez e Petróleo: Uma análise da nova política econômica venezuelana. Cadernos PROLAM/USP. São Paulo, Ano 5, v. 2, p. 209-237, 2006.

USLAR PIETRI, Arturo. Los Venezolanos y el Petróleo. Caracas, Monte Ávila, 1990.

VENEZUELA. 1999: Año de la Fundación de la República: selección de discursos del Presidente de la República Bolivariana de Venezuela, Hugo Chávez Frias. Caracas, Ediciones de la Presidencia de la República, 2005,t.1.

Recebido em 10/03/2010

Aprovado em 01/02/2011 